\title{
Erratum to: Simulating experiment on the en- richment of precious metals in Lower Cambrian black shale series of Hunan and Guizhou provinces
}

\author{
HAN Tao ${ }^{1,2}$, ZHU Xiaoqing ${ }^{1 *}$, and LI Zengsheng ${ }^{1,2}$ \\ ${ }^{1}$ The State Key Laboratory of Ore Deposit Geochemistry, Institute of Geochemistry, Chinese Academy of Sciences, Guiyang 550002, China \\ ${ }^{2}$ Graduate University of Chinese Academy of Sciences, Beijing 100049, China \\ *Corresponding author,E-mail: zhuxqcas@sohu.com
}

Received November 10, 2010; accepted December 20, 2010

(C) Science Press and Institute of Geochemistry, CAS and Springer-Verlag Berlin Heidelberg 2011

Erratum to: Chin.J.Geochem.(2011)30:375-381

DOI: $10.1007 / \mathrm{s} 11631-011-0522-6$

In Fig. 2, the scale is $100 \mathrm{~nm}$, but not $100 \mu \mathrm{m}$.

The online version of the original article can be found at http://dx.doi.org/10.1007/s11631-011-0489-3 